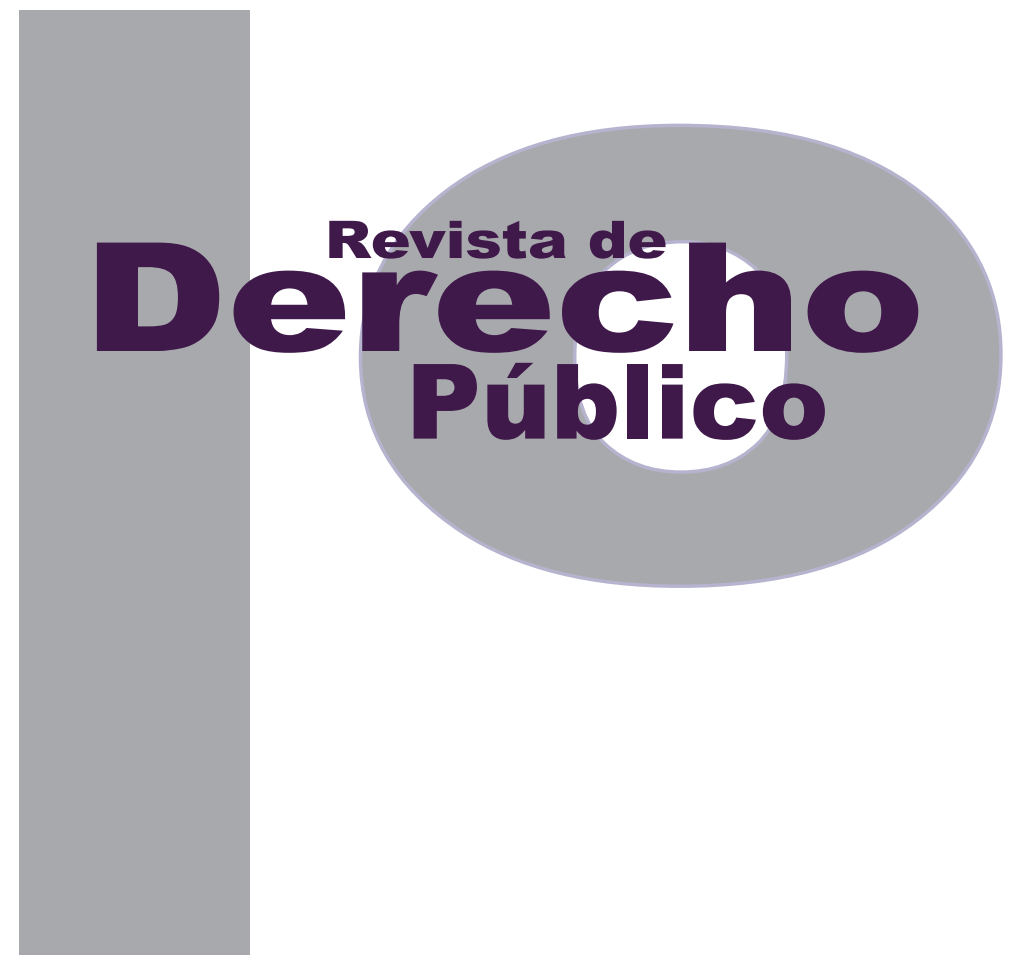

THE RECENT ATTEMPT AT CONSTITUTIONAL REFORM TO COLOMBIA'S MILITARY JURISDICTION: CONTEXT, IMPLICATIONS AND PERSPECTIVES FOR SUBSEQUENT DEBATES

\author{
AlejANDRo GómEZ- VeLÁsQUez \\ Artículo de reflexión \\ DOI: http://dx.doi.org/10.15425/redepub.33.2014.15 \\ Universidad de los Andes \\ Facultad de Derecho \\ Revista de Derecho Público N. ${ }^{\circ} 33$ \\ Julio - Diciembre de 2014. ISSN 1909-7778
}




\title{
The recent attempt at constitutional reform to Colombia's military jurisdiction: Context, implications and perspectives for subsequent debates
}

\begin{abstract}
From an international perspective, there has been a tendency to try and restrict or even avoid the use of military tribunals to prosecute members of the military or police responsible for serious human rights violations. Colombia has become a part of this trend over the past few decades, particularly through its Constitutional Court jurisprudence and a handful of legislative developments. However, Colombia's Legislative Act 02 of 2012 interrupted this trend by attempting to amend the country's Constitution and extend the scope of military jurisdiction in Colombia, arguing that more confidence should placed in Colombia's military and police. Although Colombia's Constitutional Court quickly declared this constitutional reform unconstitutional due to some flaws in the congressional approval process, the substantial content and implications of this attempt at reform must be the starting point for subsequent debates about the benefits and scope of military criminal justice reform.
\end{abstract}

Keywords: Military Jurisdiction, International Humanitarian Law, Human Rights Law, Constitutional Court, constitutional reforms.

\section{El intento de reciente reforma constitucional a la jurisdicción militar en Colombia: contexto, implicaciones y perspectivas para debates posteriores}

\section{Resumen}

En el ámbito internacional se ha venido consolidando una tendencia consistente en restringir o incluso prohibir el uso de tribunales militares para la persecución de miembros del ejército o de las fuerzas de policía que han sido responsables por la comisión de graves violaciones a los derechos humanos. Durante las últimas décadas, Colombia había hecho parte de esta tendencia, especialmente a través de la jurisprudencia de la Corte Constitucional y de recientes reformas legislativas. Sin embargo, con la expedición del Acto legislativo 02 de 2012, ésta tendencia se vio interrumpida, ya que con el argumento de generar certeza en las labores de las fuerzas militares y de policía, se procedió a extender el ámbito de aplicación de la justicia militar en Colombia. A pesar que éste intento de reforma constitucional fue rápidamente declarado inconstitucional por la Corte Constitucional por vicios en su proceso de aprobación en el Congreso de la República, sus contenidos e implicaciones deberán ser tenidos en cuenta como punto de partida para futuras discusiones en el tema.

Palabras clave: Jurisdicción Penal Militar, Derecho Internacional Humanitario, Derecho Internacional de los Derechos Humanos, Corte Constitucional, reformas constitucionales.

\section{A tentativa da recente reforma constitucional à jurisdição militar na Colômbia: contexto, implicações e perspectivas para debates posteriores}

\section{Resumo}

No âmbito internacional vem se consolidando uma tendência consistente em restringir ou inclusive proibir o uso de tribunais militares para a persecução de membros do exército ou das forças de polícia que têm sido responsáveis pela comissão de graves violações aos direitos humanos. Durante as últimas décadas, a Colômbia tinha feito parte desta tendência, especialmente através da jurisprudência da Corte Constitucional e de recentes reformas legislativas. Porém, com a expedição do Ato Legislativo 02 de 2012, esta tendência se viu interrompida, já que com o argumento de gerar certeza nos trabalhos das forças militares e de polícia, se procedeu a estender o âmbito de aplicação da justiça militar na Colômbia. Apesar que esta tentativa de reforma constitucional tenha sido rapidamente declarada inconstitucional pela Corte Constitucional por vícios em seu processo de aprovação no Congresso da República, seus conteúdos e implicações deverão ser levados em consideração como ponto de partida para futuras discussões no tema.

Palavras-chave: Jurisdição Penal Militar, Direito Internacional Humanitário, Direito Internacional dos Direitos Humanos, Corte Constitucional, reformas constitucionais. 


\title{
The recent attempt at constitutional reform to Colombia's military jurisdiction: Context, implications and perspectives for subsequent debates* $^{*}$
}

\author{
Alejandro Gómez- Velásquez**
}

\begin{abstract}
SUMARIO
Introduction - I. MILITARY CRIMINAL JURISDICTION IN COLOMBIA BEFORE THE ATTEMPT AT CONSTITUTIONAL REFORM - A. Military jurisdiction under the 1991 Colombian Constitution and Constitutional Court Jurisprudence - B. Legislative Act 02 of 1995 and Constitutional Court Decision C-358/97 - C. Law 522 of 1999: The New Military Code - D. Holdings from the Superior Council of the Judicature on military jurisdiction - E. Colombia's "false positive" phenomenon and the military forum - F. Military jurisdiction before the attempt at constitutional reform - II. THE ATTEMPT AT CONSTITUTIONAL REFORM TO THE MILITARY CRIMINAL JURISDICTION: LEGISLATIVE ACT 02 OF 2012 - A. Background and justification of the proposed reform - B. Process and approval of the Constitutional reform - C. The Constitutional reform's content and implications - D. The un-constitutionality of Legislative Act 02 of 2012. III. CONCLUSIONS - Bibliography.
\end{abstract}

\footnotetext{
* How to cite this article: Gómez- Velásquez, A. (Diciembre de 2014). The recent attempt at constitutional reform to Colombia's military jurisdiction: Context, implications and perspectives for subsequent debates. Revista de Derecho Público, 33. Universidad de los Andes (Colombia).

** Lawyer, Political Scientist and Specialist in Public Law from the Universidad EAFIT; Master in Constitutional Law from the Centro de Estudios Políticos y Constitucionales, (Madrid- España); LL.M in International Legal Studies from American University (Washington D.C); and Assistant Professor in Public Law at Universidad EAFIT (Medellín- Colombia). Email: agomezv1@eafit.edu.co
} 
Introduction

In the last two decades, the discussion and practice of international human rights law has focused on preventing the impunity of actors who have committed gross international human rights violations and breached international humanitarian law. This trend can be evidenced by the creation of international ad hoc tribunals and the International Criminal Court's Rome Statute. Military jurisdiction has been a particular focus of debate in acts where questions of impunity are at issue. It has historically been used during military regimes across much of Africa, Asia, Europe and especially Latin America, but has also functioned during democratic periods in these regions and academics and advocates in the field of international human rights have identified military jurisdiction as perpetuating abuse and impunity.

Some of the most serious criticisms and concerns of military tribunals have arisen from its use of trying members of State led security forces who have committed gross or serious human rights violations and/or breaches of International Humanitarian Law. To some experts, this practice is precisely "one of the greatest sources of impunity in the world" ${ }^{1}$. This begs the larger question of whether military jurisdiction is compatible with the obligation under international human rights law to administer justice for victims of gross human rights violations.

1 Federico Andreu- Guzmán. Military Jurisdiction and International Law: Military Courts and Gross Human Rights Violations, vol 1 (Geneva: International Commission of Jurists, 2004) at 12.
Conversely, there are strong advocates of the military justice system, especially among military personnel, who argue that the justification and purpose of these military tribunals is to allow the armed forces to deal with matters that pertain directly to military discipline, efficiency and morale. For them, the raison $d$ être of the military justice system is compatible, in principle, with the normative requirements of international human rights and international humanitarian law. However, military justice systems must not only be compatible, but must also comply with these international requirements. According to advocates of the military criminal justice system, once this compliance has been achieved and the military courts possess sufficient integrity, independence and impartiality, then they should be capable of trying grave offences committed by military personnel, even for serious human rights violations ${ }^{2}$.

Despite the lack of regulation on this particular issue by international human rights instruments ${ }^{3}$, it is possible to identify a doctrinal and jurisprudential trend developed by inter-governmental human rights bodies that try to restrict or even avoid the use of military courts to prosecute military or police officers who have perpetrated or aided and abetted in the commission of gross human rights violations. The main argument by

2 A strong defense of military jurisdiction can be found in: Michael R. Gibson. International Human Rights Law and the Administration of justice through Military Tribunals: Preserving utility while precluding impunity. 4 J. Int'I \& Int'I Rel. 1 (2008).

3 So far only two international instruments contain specific restrictions on military jurisdiction with regard to gross human rights violations. They are the United Nations Declaration on the Protection of All Persons from Enforced Disappearance and the Inter-American Convention on Forced Disappearance of Persons. 
these bodies is that when the conditions of impartiality and independence are not present in the structure and operation of a military court such that the verdict is sure to result in impunity, the State inherently violates its obligations to investigate, punish and provide truth and reparations to victims of atrocities under international and human rights law. The discussion on this point is whether military courts, depending on their background and composition, could be impartial and independent enough to avoid impunity and truly impart justice under the international standards for human rights violations.

Although there are strong advocates on both sides, it is possible to argue that the international trend in this particular issue is addressed to limit and restrain the scope of the military jurisdiction for those types of violations. This tendency can be evidenced both from a normative and practical point of view. From the practical side, the growing number of countries in which military jurisdiction is being reformed is encouraging. In this sense, many countries have abolished military courts in peacetime or have introduced safeguards into their legislation in order to ensure that gross human rights violations are removed from military jurisdiction ${ }^{4}$. From the normative side, the Special Rapporteur of the United

4 The last of those decisions was by the Supreme Court of Justice of the United States of Mexico, which established in an Amparo de Revision on August 21, 2012 that "if a military judge were to hear a criminal case where the victim of a crime or offense was a civilian, it would be exercising jurisdiction thereof, in contravention of Article 13 of the Constitution". Thus, all cases that have civilian victims must be tried in ordinary courts. Amparo de Revisión 133/2012. "Inconstitucionalidad del artículo 57, fracción II, inciso a) del Código de Justicia Militar y legitimación del ofendido y sus familiares para promover amparo", 21/08/12, http://www2.scjn.gob.mx/AsuntosRelevantes/pagina/SeguimientoAsuntosRelevantesPub.aspx?ID=136182\&SeguimientolD=478
Nations Sub- Commission on the Promotion and Protection of Human Rights, with the support of the Office of the High Commissioner for Human Rights, has recently produced a set of Draft Principles Governing the Administration of Justice Through Military Tribunals ${ }^{5}$ with the intention that it be considered and adopted by the Human Rights Council as a bulwark on this matter. Regarding the possibility of military courts trying persons accused of serious human rights violations, the ninth principle of the draft establishes that "[i]n all circumstances, the jurisdiction of military courts should be set aside in favor of the jurisdiction of the ordinary court to conduct inquiries into serious human rights violations" ${ }^{6}$.

Until now, Colombia has served as a good example of the restrictive trend on military jurisdiction in the past few decades. After the enactment of the Constitution of 1991, especially through the use of Constitutional Court jurisprudence and other regulatory developments, a normative framework was created to prevent military courts from hearing and prosecuting perpetrators of human rights violations. In the past few years, the courts have increasingly supported this new framework of prosecuting military officials for human rights violations, which, as I argue further on, has helped reduce the commission of these serious crimes.

Nevertheless, this hopeful example against impunity and in favor of justice and human rights

\footnotetext{
5 Draft Principles Governing the Administration of Justice Through Military Tribunals, 62d Sess., UN Doc. E/CN.4/2006/58 (January 13, 2006).

$6 \quad$ Id.
} 
was suddenly interrupted by a congressional constitutional reform known as Legislative Act 02 of 2012. Fortunately, ten months after the enactment of this reform, the Constitutional Court in a controversial decision declared Legislative Act 02 of 2012 unconstitutional based on procedural errors during the legislative process ${ }^{7}$.

In light of this context, this paper seeks to thoroughly and critically analyze this frustrated attempt by Colombia's congress at constitutional reform by addressing the political reasons behind the reform's creation as well as some legal and constitutional arguments that are required in order to understand the real implications and perspectives of such a proposal. Accordingly, this article aims to document the development of an attempt by Colombia's congress to constitutionally reform the country's military justice system and serves as a starting point for future congressional initiatives and further discussion on the issue. With this in mind, the first section of this paper shall focus on the context in which the attempt of the constitutional reform took place, explaining the developmental framework and military criminal jurisdiction in Colombia before the constitutional reform. The second section shall address the background, procedural history, approval and some preliminary implications leading up to the point when Colombia's Constitutional court declared Legislative Act 02 of 2012 unconstitutional.

7 Corte Constitutional [C.C.] [Constitutional Court], October 23, 2013, Sentencia C-740 de 2013.

\section{MILITARY CRIMINAL JURISDICTION IN COLOMBIA BEFORE THE ATTEMPT AT CONSTITUTIONAL REFORM}

\section{A. Military jurisdiction under the 1991 Colombian Constitution and Constitutional Court Jurisprudence}

Military criminal jurisdiction has historically received constitutional support in Colombia ${ }^{8}$. Article 221 of the Colombian Constitution of 1991 established that "crimes committed by members of the security forces on active duty and in relation to the same service will be recognized by the martial courts or military tribunals, in accordance with the provisions of the Military Criminal Code" ${ }^{\prime}$. Article 221 and other related constitutional provisions suggest that the military jurisdiction in Colombia has five main features: First, that the military courts belong to the government ${ }^{10}$ and not to the judicial branch; Second, that military jurisdiction constitutes one of the exceptions to the ordinary civil jurisdiction; Third, that this military forum only applies to active members of State led security forces

8 For more on the history of military jurisdiction in Colombia see Federico Andreu- Guzmán. Op Cit. p. 203. CONSTITUCION POLÍTICA DE COLOMBIA [C.P] art. 221. Original version.

10 The Colombian Constitution lists the organs that belong to the judicial branch. The martial or military courts are not among this list .Their absence from this list has served as a sufficient argument for the Constitutional Court to hold that the military jurisdiction thus does not belong to the judicial branch but rather is seated within the executive branch. Under this reasoning the Court has declared unconstitutional a law that tried to make military courts part of the judicial branch, holding "...as indisputable, then, that the military judges do not have to be part of the judicial branch, this Court shall declare the law unconstitutional". See: Corte Constitutional [C.C.] [Constitutional Court], February 5,1996, Sentencia C-037/96. 
and when their conduct is related to the service of these forces; Fourth, that the military court's composition, procedures and rules are based on the Military Criminal Code, which has the nature of an ordinary law enacted by Congress and is subordinate to the Constitution; and Fifth, that military courts cannot investigate or try civilians, even in a state of emergency ${ }^{11}$.

When the Constitution was enacted in 1991, the Military Criminal Code was included as a provision, which had been left over from Decree 2550 of 1988 and had therefore been enacted under different principles and constitutional values ${ }^{12}$. The inclusion of this Military Criminal Code in the new Constitution sparked a series of judicial review actions of some the Code's articles. The Constitutional Court, as the new and competent organ to hear and decide such matters, took a restrictive approach towards the scope of the military jurisdiction and held that military justice should be harmonized with other principles, values and rights that coexisted in the new Constitution. According to this reasoning, the Constitutional Court held in Decision C-141 of 1995 that,

[T]he military jurisdiction cannot be understood, as it has been in the past, as an idea of privilege, prerogative, perk or special grace for the trial of members of the armed forces for crimes committed against the civil population during their service, under different legal or material conditions, which occurred at a time

11 CONSTITUTION POLÍTICA DE COLOMBIA [C.P] art. 213.

12 Decree 2550 of 1988 was a provision created by the President with special powers delegated by a law from the National Congress. See D/L. 2250, diciembre 12, 1998, DIARIO OFICIAL [D.O]. when any State led criminal prosecution only resulted in impunity, as this would mean granting special treatment, contrary to the principle of equality and the idea of justice ${ }^{13}$.

One provision of the Military Criminal Code established the possibility that the martial courts or military tribunals could correspond to active duty military or police personnel. Despite the silence of the Constitution on this particular point, the Constitutional Court declared this provision unconstitutional because, according to the Court's decision, "there are no guarantees of independence and impartiality in the duty to impart justice if those involved in the judging process are active duty officers, as those officials have a relationship of dependence and subordination, a hierarchical link with the institution and especiaIly with their superiors" ${ }^{14}$. Therefore, since this ruling, all martial courts and military tribunals were only to be composed of retired officials or civilians. In the words of the Court:

$[T]$ he social conflict situation faced by the country for the last several years places members of the forces of public order [...] in a situation where they must participate in the different repressive actions required to subdue the enemies of the [institutional] order and, at the same time, serve as judges of the excesses committed in the course of those actions which constitute crimes $^{15}$.

13 Corte Constitutional [C.C.] [Constitutional Court], March 29 1995, Sentencia C- 141/95.

14 ld.

15 Id. 
Thus, it was clear that the Court had serious concerns about the independence and impartiality of the military courts in participating in the conflict and their ability to subsequently conduct due diligence in an any investigation and/or judgment involving their own abuses.

\section{B. Legislative Act 02 of 1995 and Constitutional Court Decision C-358/97}

As an almost immediate reaction to this decision and under pressure from military forces, Congress enacted Legislative Act 02 of $1995^{16}$. This constitutional amendment ${ }^{17}$ was passed just nine months after the Court's decision to restrict military jurisdiction and through a dubious legislative process ${ }^{18}$ Article 221 of Colombia's Constitution was amended to read that:"[...] such courts and tribunals will be integrated by active duty or retired military personnel". As a result, military courts were exclusively comprised of military officials.

16 L./A 02, diciembre 21, 1995, DIARIO OFICIAL [D.O]

17 According to news reports from that time, high ranking military and national police officers and were in the Congress during the days when the constitutional amendment was approved.

Congress used for this constitutional amendment the strategy of "joint committees", meaning that the senate and the chamber of representatives gathered together to discuss and decide about a proposal avoiding with that the ordinary legislative process that requires debates and decisions in both chambers. The provision that allows this practice was later declared unconstitutional by the Constitutional Court in the ruling Number C-365 of 1996. With this same argument Legislative Act 02 of 1995 was then deemed unconstitutional but in a controversial decision by the Constitutional Court the constitutional reform was declared constitutional for the sake of the "judicial security". See Corte Constitutional [C.C.] [Constitutional Court], August 22, 1996, Sentencia C-387/96.
Despite doubts about the legality of this reform, it was evident it had occurred as part of a political backlash to the Court's 1995 decision in C-141 to exclude military and police personnel from holding positions of power in a martial court or military tribunal. Despite congressional enactment of Legislative Act 02 of 1995, the Constitutional Court made another historic decision involving military jurisdiction in Decision C-358 of $1997^{19}$. In this case, a Colombian citizen claimed the unconstitutionality of a group of Military Criminal Code provisions arguing that the military and ordinary jurisdiction were unequal because some criminal offenses listed in the Military Code had less severe sentences than in the Ordinary Code. To resolve this issue, the Court reiterated that military jurisdiction is an exception to the constitutional principle of a civilian trial judge (juez natural) ${ }^{20}$ and therefore there is a limited role that military courts should have in Colombia's constitutional system.

Based on this thesis, the Court proceeded to interpret the scope of Article 221 of the Constitution and set forth two elements that must be met before enacting military jurisdiction. The first element is subjective and states that the perpetrator must be a member of the armed forces and in active duty. The second element is more functional than subjective and states that

19 The Inter-American Commission of Human Rights has said that this decision "constitutes a truly meritorious step by the State entity in Colombia's struggle toward full human rights protection". IACHR, Third Report on the Situation of Human Rights in Colombia. 1999, Chapter V, p. 7 .

20 To the Court this principle is part of the fundamental right to due process established in Article 29 of the Constitution. See Corte Constitutional [C.C.] [Constitutional Court], June 24, 1994, Sentencia T-295/94. 
the perpetrator's conduct must be "related to the [military or police] service". The term "service" in this context, means "concrete activities that are addressed to fulfill and accomplish the military's true purpose, such as defense of sovereignty, independence, territorial integrity and national constitutional order. For the national police "service" means maintaining the conditions necessary for the exercise of rights and public freedoms and peaceful coexistence" 21 .

The Court used these two elements to hold that, the perpetrator must be an active member of the military or police force and his/her conduct must have a close and direct link with legitimate military and police activity in order for the crime to fall under military jurisdiction. Hence, the mere fact that the perpetrator is a member of the military or police force is insufficient to claim military court jurisdiction. Second, the Court held that the link between the criminal conduct and any military or police related activity is broken when the crime is unusually grave, as in the case of crimes against humanity. In the words of the Court:

A crime against humanity is so far removed from the constitutional role of the military and police force that it can never be legitimately tied to military and/or police service, as the mere commission of such crimes dissolves any possible link between the agent's conduct, his discipline, and any inherent military or police

21 Corte Constitutional [C.C.] [Constitutional Court], August 5, 1997, Sentencia C-358/97. function, such that any such acts fall within the purview of the ordinary courts ${ }^{22}$.

Therefore, the Court declared Military Criminal Code articles yielding milder sentences than the Ordinary Code, as well as any other provision that granted any type of extension of military jurisdiction to be unconstitutional. In this respect, the Court held that going beyond the conducts strictly related with the service of the armed forces constitutes a violation of the limitation that the Constitution's constituents made to the application of the military justice system in Colombia.

\section{Law 522 of 1999: The New Military Code}

Due to the large number of provisions declared unconstitutional in the Military Code, the Government proposed a new military code in a bill sent before Congress. Although the bill took into account the Constitutional Court's prior holdings, the final approved text did not clearly reflect these considerations.

For example, Article 3 of the bill sought to define the military and police conduct but excluded the Court's terminology about a broken link between the criminal conduct and any military or police related activity when the crime is unusually grave. The bill stated that "any case of torture, genocide, forced disappearance or any other conduct that constitutes grave violations of human rights, human dignity or sexual liberty

22 Id 
could be considered related to military or police service" ${ }^{23}$. Therefore, Congress decided to close the spectrum and created an exhaustive list of conducts in which the exclusion should be presumed, arguing that at the end of the day any criminal conduct could be considered a violation of human rights and therefore military jurisdiction could practically be dismantled ${ }^{24}$. Thus, in Article 3 of Law 522 of $1999^{25}$, the new Military Criminal Code, allows “[...] any crimes of torture, genocide and forced disappearance to be considered related to military and/or police service as per the terms defined in covenants or international treaties ratified by Colombia".

In 2000, the Constitutional Court ruled on some of the new Military Code's articles, including Article 3. In Decision C-878 of 2000 , the Court conditioned the constitutionality of the new Military Code's articles by ordering that they be interpreted using the Court's prior rulings, with particular attention to Decision C-358 of 1997, where the Court reiterated the limited role of military courts. The Court also conditioned Article 3's constitutionality by stating that "the crimes listed therein are not the only criminal acts that have been excluded from military jurisdiction, as any such acts which could be considered openly contrary to the constitutional function of the armed forces and the commission of such acts alone breaks the functional nexus between the agent

23 Congreso de la República [National Congress], Gaceta del Congreso [Congress Gazette], No. 26 of 1998.

24 Congreso de la República [National Congress], Gaceta del Congreso [Congress Gazette], No. 484 of 1998.

25

L. 522/99, August 13, 1999, DIARIO OFICIAL [D.O.] and his service, such that the act shall be considered as excluded from the competence of this special jurisdiction"26. Thus, the Court invoked its earlier decisions and applied them to the new Military Code. Unfortunately, this application did not lead to a significant change in the number cases involving military and police officers accused of human rights violations being brought before ordinary courts. Rather, all significant cases still remained in the military jurisdiction.

\section{Holdings from the Superior Council of the Judicature on military jurisdiction}

According the Inter-American Commission on Human Rights (IACHR), several State entities and institutions, such as the Superior Council of the Judicature (Consejo Superior de la Judicatura), were responsible for ruling on the grave crimes committed by military or police officers whose cases remained in military courts ${ }^{27}$.

According to Colombia's Constitutional Article 256.6, the Superior Council of the Judicature resolves jurisdictional disputes or conflicts of competence hailing from different jurisdictions. This power, added to the functional autonomy of the Council, created some difficulties and delays in the adoption of the Constitutional Court's decisions $^{28}$. Rather, the Council continued to apply a

26 Corte Constitutional [C.C.] [Constitutional Court], July 12, 2000, Sentencia C- $878 / 00$

Inter-American Commission on Human Rights, Third Report on the Situation of Human Rights in Colombia. 1999, Chapter V, p. 9.

Regarding this issue the IACHR stated in its report that "Traditionally [the Superior Council of Judicature] sent almost all cases involving crimes allegedly committed by members of the security forces to the military jurisdiction, without seriously analyzing the requirement of 
very broad interpretation of the elements of the acts committed in relation to military service, and thus the majority of cases involving military and police and human rights violations were referred to military courts.

As a result, the Constitutional Court on occasion used its discretional power to revise judicial decisions of the writ of protection for fundamental rights (acción de tutela) and review the Council's decisions on jurisdictional disputes related to the military jurisdiction to ensure the adoption of the Court's doctrine. The most famous of those cases, Decision SU-1184 of 2001 addresses the alleged links between the paramilitary groups and the military officials, including a Colombian Army General.

Decision SU-1184 of 2001 refers to a writ of right (acción de tutela) against a Council decision involving a conflict of jurisdiction matter between the military courts and ordinary jurisdiction to prosecute the army commanders stationed in the territory where a paramilitary massacre of 49 people occurred in 1997 in Mapiripan, Meta, Colombia. In its revised decision, the Superior Council determined that the omissions of these officials were related to the service and functions of the armed forces and therefore fell under military jurisdiction.

The Constitutional Court repealed the Council's decision and based its reasoning on the "gua-

connection to service. The tribunal also resisted with vehemence any suggestion that the military jurisdiction should not receive cases involving crimes against humanity or other particularly serious human rights violations. The tribunal at one point stated that any such suggestion formed part of a "pseudo- Marxist" current of thought". Idem. P. 7. rantor position" which holds that military officials have an obligation to prevent the commission of grave human rights violations in the territory where they are stationed, particularly when there is a high indication that the commission of such crimes will occur. From there, the Court analyzed the possible link between the omissions of these officials and their official role and function as granted to them under the Constitution and concluded that "only if there is no doubt about the relation between the [military] service and the act subject to investigation, is it then possible to assign competence to the military criminal jurisdiction" 29 . Therefore, in this case, the Court found reason to doubt the link and ordered the Council to refer the case to the ordinary system, in accordance with the Court's analysis and holding.

Initially, the Superior Council refused to adopt the Constitutional Court's holdings in these types of cases. However, in 2006, the Council began to accept and apply the Court's decisions to the extent they involved issues of military jurisdiction. The following is one of a number of Court decisions ${ }^{30}$ adopted by the Superior Coun$\mathrm{cil}^{31}$. In 2006, in a complex case involving the murder of ten police officers and one civilian by a group of army soldiers during a drug tra-

29 Id.

30 See also: Corte Constitutional [C.C.] [Constitutional Court], August 21, 2002, Sentencia T-677 of 2002.

31 "The Constitutional Court and the Superior Council of the Judicature have clarified that the military courts do not have jurisdiction when members of the State's security forces engage in acts that are permitted to them under the constitutional functions of the forces (such as unlawful killings) and that where there is doubt, civilian jurisdiction should apply" 
fficking operation in Valle del Cauca, the Superior Council decided to confer jurisdiction to the ordinary authorities because "according to the facts, there are doubts that prohibit the clear determination of whether the death of the ten police officers and one civilian was caused by a fatal mistake, or on the contrary, caused intentionally by military officials" 32 . Thus, from 2006 onward, the Council's willingness to incorporate and accept of the Constitutional Court's jurisprudence in cases involving the scope of military jurisdiction marked a clear turning point in favor of constitutional doctrine.

\section{E. Colombia's "false positive" phenomenon and the military forum}

Likewise in 2006, attending to suspicions about the increase of civilian deaths at the hands military forces (which would later infamously become known as the "false positives" scandal) and in response to international pressure on these issues, ${ }^{33}$ the Uribe administration made a decision that heavily impacted the development of the military jurisdiction in the years to come. In June of that year, Colombia's Defense Minister and it's Attorney General signed a memorandum of agreement entitled "Support for Military

32 Consejo Superior de la Judicatura [Superior Council of Judicature], Sala Jurisdiccional- Disciplinaria, August 14, 2006, Expediente 11001010200020060112100

33 According to some public media outlets, the Government made this decision under international pressure, especially by NGOs and international governments that had expressed their concern about the possibility that the war against the guerilla groups was not "transparent" enough and was in fact acting as a shield for military and police involved in the commission human rights violations. http://www.semana. com/politica/articulo/fuero-militar-enredo-alvaro-uribe/255288-3
Criminal Justice" 34 in which the parties agreed that: (i) in all cases of deaths arising from to the actions of the armed forces, inspection of the crime scene and gathering of evidence shall be conducted exclusively by members of the CTI (Cuerpo Técnico de Investigación) which is a group technical investigators who answer solely to the Attorney General's Office, as opposed to the police; and (ii) all evidence recovered by these CTI investigators shall be delivered to an ordinary prosecutor who will decide if they have jurisdiction over each of the cases or if the elements for military jurisdiction are met and therefore the case should be transferred to a military court. Put into practice, these two factors allowed the ordinary jurisdiction to be the first to receive all cases related with military personnel and to keep the cases that it felt did not fulfill the elements of military jurisdiction; this was done without the need for any decision by the Superior Council of Judicature.

At the end of 2008 the "false positives" scandal broke. The term "false positives" referred to the practice of some members of Colombia's national security forces "carrying out a significant number of premeditated civilian murders and fraudulently presenting these civilians as having been killed in combat"35. Despite the emergence of this scandal in 2008 , the practice was

34 Ministerio de Defensa Nacional y Fiscalía General de la Nacion, "Apoyo a la Justicia Penal Militar", http://www.cgfm.mil.co/CGFMPortal/Cgfm_files/Media/File/Circulares\%20OADYA/Circular-No.\%20 433-CGFM-CGING-INGDA-743-29-JUN-2006.PDF

35 Philip Alston, "Report of the Special Rapporteur on extrajudicial, summary or arbitrary executions- Mission to Colombia", A/HRC/14/24Add.2 (March 31, 2010), http://daccess-dds-ny.un.org/doc/UNDOC/GEN/ G10/132/35/PDF/G1013235.pdf?OpenElement 
not new among Colombia's security forces ${ }^{36}$ and it was clear by then that multiple military units around the country were involved ${ }^{37}$. This scandal combined with the media's coverage on impunity associated with trying these national security forces in a military court severely blemished the military and police's image and placed doubt among international human rights organizations about the legitimacy and competence of Colombian's disciplinary authorities and it's military jurisdiction.

After his visit to Colombia is 2010, the former UN Special Rapporteur on Extrajudicial, Summary or Arbitrary Executions stated that despite clear judicial rulings by the Constitutional Court and the Superior Council of Judicature ${ }^{38}$ and the memorandum of understanding between the Defense Ministry and the Office of the Attorney General too many cases of unlawful killings, among other human rights violations, continued to be heard in military courts and thus " $[\mathrm{t}] \mathrm{he}$ most significant obstacle to effective prosecution of extrajudicial executions committed by members of the military and police forces is the continuing jurisdictional conflicts between these two systems and the failure by military judges to transfer these cases to the civilian justice system"39.

It was precisely during the "false positive" scandal that Congress addressed a new bill which proposed a new Military Criminal Code. In August 2010, after some presidential objection to the congressionally approved text, which had the support of the Constitutional Court ${ }^{40}$, Congress enacted Law 1407 of 2010 as the new Military Criminal Code. In passing this new law, it was clear that Congress and especially the Government, presumably highly affected by the "false positives" scandal, sought to further restrict the scope of military jurisdiction, as this new code adopted the Constitutional Court's prior holdings and expanded the list of conducts that de iure cannot be considered as being related to military and/or police service, specifically:

[...]crimes of torture, genocide, enforced disappearance, crimes against humanity or those [acts] which violate international humanitarian law in the terms defined by international conventions and treaties ratified by Colombia, or any conduct which is openly contrary to the constitutional role of the military or police forces and that by their mere commission break the functional connection between the officer and his military or police service ${ }^{41}$.

36 The first documented "false positive" case was in 1984 in the Colombian department of Antioquia. The U.S. Embassy in Colombia has possessed knowledge about this practice since 1990, thus, it is arguable whether the occurrence of "false positives" is a new phenomenon in Colombia. See http://www.eltiempo.com/justicia/ARTICULO-WEBNEW_NOTA_INTERIOR-10801885.html

37 Philip Alston, Op. Cit.

38 Consejo Superior de la Judicatura [Superior Council of Judicature], Sala Jurisdiccional- Disciplinaria, July 30, 2011, Expediente 11001010200020110125700 .
39 Philip Alston, "Report of the Special Rapporteur on extrajudicial, summary or arbitrary executions- Mission to Colombia", A/HRC/14/24Add.2 (March 31, 2010), http://daccess-dds-ny.un.org/doc/UNDOC/GEN/ G10/132/35/PDF/G1013235.pdf?OpenElement

40 Corte Constitutional [C.C.] [Constitutional Court], August 21, 2002, Sentencia T-677 of 2002 and Corte Constitutional [C.C.] [Constitutional Court], May 28, 2008, Sentencia C-533/08.

41 L. 1407/10, August 17, 2010, DIARIO OFICIAL [D.O.]. Article $3^{\circ}$. 
Hence, the Constitutional Court's prior holdings about the functional element of the perpetrator's conduct being "related to the [military or police] service" was recognized and expressly incorporated into this new Military Criminal Code.

\section{F. Military jurisdiction before the attempt at constitutional reform}

In summary, because this new law incorporated of the holdings from Colombia's highest courts ${ }^{42}$ and was influenced by international tribunals ${ }^{43}$, military jurisdiction could be defined at this point by the following features: (i) the military jurisdiction and subject matter are considered restricted and exceptional; (ii) the crime must have been committed by a member of the military or police force on active duty (the subjective element) and in close and direct relation with military or police service as enshrined in the constitution (the functional element); (iii) if the link between the criminal conduct and any military or police related activity is broken when the crime is unusually grave, as in cases of torture, genocide, forced disappearance, crimes against humanity or when the crime violates international humanitarian law as set forth in international conventions and treaties ratified by Colombia, then that case will be subject to ordinary jurisdiction. This list of cases is not exhaustive; (iv) the inspection of the crime scene and the gathe-

42 At this time, in conformance with Constitutional Court and Superior Council of Judicature jurisprudence, the Supreme Court, as the highest court of the ordinary jurisdiction, adopted the same doctrine regarding military jurisdiction. See Corte Suprema de Justicia [C.S.J] [Supreme Court of Justice], marzo 23, 2011, Casación 35.099.

Regarding the influence of international tribunals, especially the InterAmerican Court of Human Rights, see Section 3.3 of this paper. ring of evidence must be executed exclusively by the investigative division (known in Colombia as the CTI) of the Attorney General's Office; (v) all cases and evidence must be sent first to the ordinary jurisdiction and only if the facts meet the elements of the military forum can the case be transferred to a military court; and (vi) in there is any doubt about the subjective or functional element then the case should remain in the ordinary jurisdiction. The above requirements can be schematized in the following flowchart:

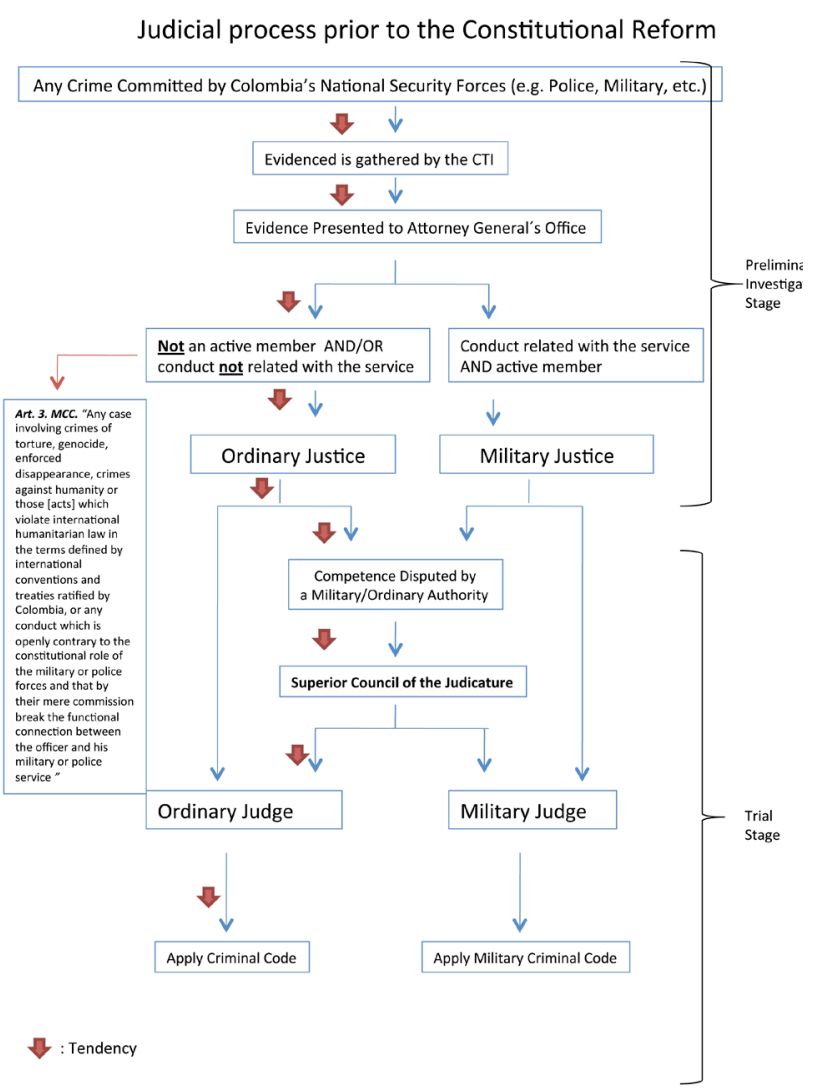

The above framework shows a strong normative trend to limit and restrict the scope of the military forum in favor of ordinary jurisdiction. This trend can also be evidenced by the Superior Council of Judicature and military authorities taking the initiative to refer more cases to the ordinary jurisdiction: 


\begin{tabular}{|l|c|c|}
\hline \multicolumn{1}{|c|}{ YEAR } & $\mathbf{2 0 1 0}$ & $\mathbf{2 0 1 1}$ \\
\hline $\begin{array}{l}\text { Number of cases referred by deci- } \\
\text { sion of a military jurisdictional au- } \\
\text { thority }\end{array}$ & 140 & 249 \\
\hline $\begin{array}{l}\text { Number of cases referred by the } \\
\text { decision of the Superior Council of } \\
\text { Judicature }\end{array}$ & 91 & 79 \\
\hline TOTAL & 231 & 328 \\
\hline
\end{tabular}

\begin{tabular}{|l|c|}
\hline Cases at trial stage & 100 \\
\hline No. of Convictions & 195 \\
$\bullet$ In Ordinary Courts & 120 \\
- Cases where the defendant plead guilty & 75 \\
\hline
\end{tabular}

Source: General Attorney`s Office, data until March 31 of 2012, quoted by Todd Howland. Panel Constitución y Fuero Penal Militar (Bogotá: Oficina del Alto Comisionado de las Naciones Unidas para los Derechos Humanos,

Source: Ministry of National Defense, (February, 2012), quoted in: Vicepresidencia de la República de Colombia, Avances de Colombia en materia de Derechos Humanos (Bogotá: Vicepresidencia de la República, 2012) at 30.

Due to this trend, for the first time in the republican history of Colombia, civil courts were being presented with crimes that exceeded the constitutional functions assigned to the military and police forces during the armed conflict. Many of these crimes involved human rights violations, thus the civil courts sentenced military and police personnel for exploiting their role as armed State actors and for violating International Humanitarian Law and international human rights law. For instance, as detailed in the chart below, of the 1,708 cases of alleged homicide by State military and police, 195 have resulted in convictions.

Cases for homicides attributed to members of the security forces and investigated by the Attorney General's Office.

\begin{tabular}{|l|c|}
\hline $\begin{array}{l}\text { Total Civil Court Cases of alleged homicide in- } \\
\text { volving State military and police }\end{array}$ & 1708 \\
\hline Open Cases & 1596 \\
- Cases under preliminary investigation & 920 \\
- Cases under investigation & 676 \\
\hline $\begin{array}{l}\text { Individuals involved } \\
\text { Members of the Military or Police }\end{array}$ & 4375 \\
\hline $\begin{array}{l}\text { Individuals accused } \\
\text { - By formal indictment (known in the prior } \\
\text { criminal code as a resolución de acusación.) }\end{array}$ & 1863 \\
- By formal indictment (known in the cur- \\
rent criminal code as a formulación de \\
acusación) & 205 \\
\hline
\end{tabular}

According to national and international human rights defenders ${ }^{44}$, the effective prosecution of military and police officials in Colombia's ordinary courts have had a dissuasive effect on the commission of "false positives" homicide.

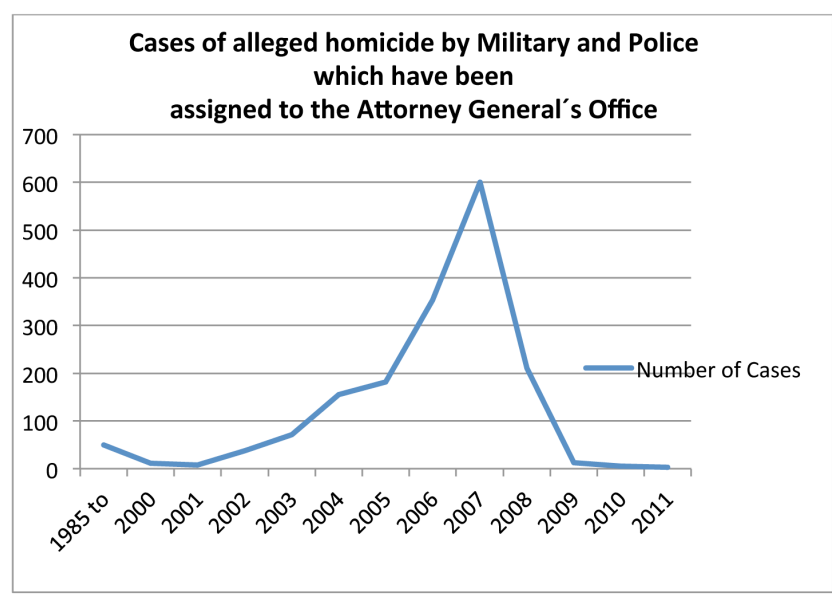

Source: General Attorney`s Office, data until March 31 of 2012, quoted by Todd Howland. Panel Constitución y Fuero Penal Militar (Bogotá: Oficina del Alto Comisionado de las Naciones Unidas para los Derechos Humanos, 2012) at 10.

In conclusion, prior to the attempt at constitutional reform, Colombia had a normative framework, which followed the international trend of requiring serious human rights violations to

44 Todd Howland, Panel Constitución y Fuero Militar, August 30, 2012, p. 11, http://www.hchr.org.co/publico/pronunciamientos/ponencias/ po144.pdf 
be prosecuted in ordinary courts as opposed to military tribunals.

\section{THE ATTEMPT AT CONSTITUTIONAL REFORM TO MILITARY CRIMINAL JURISDICTION: LEGISLATIVE ACT 02 OF 2012}

\section{A. Background and justification of the proposed reform}

The framework discussed in the last section and its practical effects bewildered the Colombian military and State police. Some of them read this situation as a new phase of a war to be waged in Colombia's courts or a so-called guerra jurídica initiated by international and domestic human rights organizations, whom they alleged to be working with insurgents in order to interrupt and demoralize the efforts of State security forces through the use of international and national legal mechanisms ${ }^{45}$. In fact, this hypothesis was widely shared among the high-ranking officers, especially in the military, who felt that the strategy was part of the broader "political war"46.

This situation was evidenced in a $2012 \mathrm{OHCHR}$ report on Colombia which stated that "The High Commissioner is seriously concerned by assertions by senior military officers that members of the Attorney General's Office and judicature are "infiltrated" guerrilla members of leftists using their powers to politically persecute members of the Armed Forces". OHCHR, Annual Report of the United Nations High Commissioner for Human Rights, 2012, A/HRC/22/17/Add.3 Presented on January 7, 2013. p.16, http://www.hchr.org.co/documentoseinformes/informes/altocomisionado/informe2012en.pdf

Vice Admiral Édgar Cely, Commander of the Military Forces at that time said in an interview that "[T]here is a political war that is being used to question [the country's defense] system. It has been traditionally used by the FARC. It is so real that there are schools in Taiwan where this is taught. The political war has a component that is legal war". http://m. elespectador.com/impreso/judicial/articuloimpreso140030-si-hayguerra-juridica
To the Colombian government and it's military commanders, the most disturbing issue was the impact of this guerra jurídica on the operability of the armed forces by delegitimizing these two major State-led institutions historically entrusted with protecting and defending the country. This concern was significant in two different ways: First, there was concern about the number of soldiers and police officers that were having to be removed from the battlefield in order to attend new judicial proceedings. This number included not only individuals who had been arrested, incarcerated and named as defendants during the development of those trials, but also individuals who had to appear as witnesses. Second, there was a concern about how the new rules, jurisdiction and standards governing military operations had spawned a lack of initiative or even inactivity among the military units and its Commanders. This concern among military personal was so prevalent that by $2010,85 \%$ of 5,000 soldiers surveyed, answered that their main fear was being incarcerated for participating in combat actions against guerrilla groups ${ }^{47}$.

Due to the seriousness of the situation, the Minister of Defense formed a high profile Advisory Commission to work on possible solutions to these issues. Three former Presidents of the Constitutional Court, two retired Generals and one former Vice-Minister of Justice sat on the Commission. According to the Commission, the main problem was the lack of legal certainty that State security forces had in their ordinary

47 La paz y la fuerza pública... jarrr!, Revista Semana, edición 1586, 22 September, 2012, p. 38-39, http://m.semana.com/nacion/articulo/lapaz-fuerza-publica-arrr/265181-3 
duties. The Commission evidenced the effects of this "legal insecurity" in three particular situations. First, the currently legal framework, especially the 2006 agreement and the new Military Criminal Code, had caused the military forum to practically disappear as ordinary courts were now hearing all cases related with military personnel; second, ordinary authorities were arresting and imprisoning military personnel for long periods of time without a conviction; and third, ordinary judicial authorities were employing human rights law standards to judge military personnel for conduct in the context of an armed conflict, but ignoring the content of International Humanitarian Law (IHL). This last situation implied that military members feared they would be criminally investigated and convicted by an ordinary court even if they had lawfully killed enemy combatants under the confines of IHL.

Based on these three situations, the Advisory Commission determined that "a comprehensive reform of the Colombia's military justice system" ${ }^{48}$ was needed. Therefore, in March 2012, the Commission suggested the need to undertake a constitutional reform, particularly through the amendment of constitutional articles 116, 152 and 221. In response to military complaints about "ambiguities" between the competence of the military and the ordinary jurisdiction to hear such cases, the text of the newly proposed article 221 maintained the original text of article 221 of

48 Fuero militar no provocará impunidad: Presidente de Comisión. Periódico El Tiempo, February 25, 2012. http://www.eltiempo.com/justicia/ARTICULO-WEB-NEW_NOTA_INTERIOR-11221141.html the Constitution ${ }^{49}$, but added a list of conducts, such as crimes against humanity, genocide, enforced disappearances, torture, extrajudicial execution, enforced displacement, rape and other sexual abuses, acts of terror against the civil population and underage recruitment, that are de iure excluded from the military jurisdiction and therefore must be recognized and judged in the ordinary jurisdiction. This list is exhaustive and thus these are the only acts perpetrated by military officials that the ordinary jurisdiction should recognize. The text also added that if there is any doubt about the possible commission of these crimes, a new commission composed of military and civilians, and no one from the Superior Council of Judicature, must initially decide on the jurisdiction of the case. In such cases, the Military Justice officers may gather and collect evidence from the crime scene, but such evidence shall only be used to resolve questions about which court (military or ordinary) is the most competent to try the dispute.

The Advisory Commission also suggested that all cases involving operations that took place during the armed conflict must "always" apply IHL as a substantive legal framework, and suggested the creation of a new type of criminal court known as a Penal Guarantees Court (Tribunal de Garantías Penales). This court would ensure the accused military official's rights were not violated during the discovery phase of a criminal trial before an ordinary or military court.

49 The original text of Article 221 states "crimes committed by members of the security forces on active duty and in relation to the same service will be recognized by the martial courts or military tribunals, in accordance with the provisions of the Military Criminal Code." 


\section{B. Process and approval of the Constitutional reform}

The Minister of Defense and the Minister of Justice approved the Advisory Commission's conclusions and on March 16, 2012, presented a bill before Congress to amend articles 116, 152 and 221 of Colombia's Constitution to reflect the Commission's proposals ${ }^{50}$. A memorandum by the Minister of Defense explaining the proposal stated that "the legal insecurity is a source of concern for the members of the Military Forces and the National Police. It is therefore necessary to have a legal framework that allows them to act effectively and without hesitation against threats that undermine the constitutional order and threats against citizens" ${ }^{51}$. Thus, from the Government's standpoint there was clear justification for the reform.

In Congress, the reform was also well received by a government coalition of political parties caIled "National Unity" which included the majority of members from both congressional chambers. Only the minority parties, such as the Polo Democrático Alternativo ${ }^{52}$, a left-leaning party and isolated members of other parties rejected the proposal. The bill passed by an overwhelming average of $91 \%$ of the votes required ${ }^{53}$ and the

50 Congreso de la República [National Congress], Gaceta del Congreso [Congress Gazette], No. 70 March 16, 2012.

51 Id

52 Reina Lucía Valencia, No se necesita ninguna reforma el fuero militar. March 14, 2012. http://www.polodemocratico.net/index. php?option=com_content $\&$ view=article $\&$ id=2201: no-se-necesita-ninguna-reforma-al-fuero-militar\&catid=64: nacionales\&ltemid $=48$

Proyecto Congreso Visible, Universidad de Los Andes, http:// twelve debates that required this type of Constitutional reform were made in an expeditious manner ${ }^{54}$.

The main discussion by Congress concerned the list of the crimes that would be excluded from military jurisdiction. The bill had proposed that crimes against humanity, genocide, enforced disappearances, torture, extrajudicial execution, enforced displacement, rape and other sexual abuses, acts of terror against the civil population and underage recruitment be excluded from military jurisdiction. However, during the legislative review process, the House of Representatives approved a shorter list comprised only of crimes against humanity, enforced disappearances and genocide ${ }^{55}$. The Senate, on the other hand, maintained the original list despite objections by some minority members to leave the list open for further legislation ${ }^{56}$.

For members of the military and State police, the amendment of this list was one of the most important points of the reform. Many high ranking military officers where present during the approval process and, as was to be expected, Congress received a great deal of pressure from them to reduce the number of crimes excluded

www.congresovisible.org/proyectos-de-ley/por-el-cual-sereforman $/ 6586 / \#$ tab=1

54Id. It only took 9 months to enact the reform.

55 Congreso de la República [National Congress], Gaceta del Congreso [Congressional Gazette], No. 706, October 19, 2012

56

Plantean revolcón a proyecto de fuero militar para evitar impunidad, Periódico El Espectador, December 11, 2012, http://www.elespectador.com/noticias/politica/articulo-391821-plantean-revolcon-proyectode-fuero-militar-evitar-impunidad 
from military jurisdiction. The influence of these Commanders over the legislators put the President of the Senate between a rock and a hard place. At that time he publicly stated that if he were to add more crimes to the list, then the Generals would view him as an adversary; but if he were to remove crimes from the list then he'd be seen as being against human rights ${ }^{57}$.

Despite overwhelming Congressional approval of the bill, national and international civil society organizations expressed significant opposition to the amendment process. Two hundred and twenty social organizations, including victims and human rights associations, sent a letter to Uribe's successor, President Santos and all the members of Congress requesting the withdrawal of the reform bill. According to the letter, such a reform would expand the scope of the military forum and therefore result in impunity for military and State police accused of human rights violations ${ }^{58}$. Colombian academics, such as Professor Yesid Reyes Alvarado ${ }^{59}$, Professor Gustavo Gallón ${ }^{60}$ and Professor Rodrigo Uprimny Yepes also publicly expressed their opposition to the bill's proposal for Constitutional reform.

57 Piden claridad al Gobierno frente a delitos a castigar en fuero militar. Periódico El Espectador, November 15, 2012, http://www.elespectador.com/noticias/politica/articulo-387179-piden-claridad-al-gobiernofrente-delitos-castigar-fuero-militar

No a la ampliación del fuero militar, Periódico El Espectador, November 15, 2012, http://www.elespectador.com/noticias/politica/articulo387307-no-ampliacion-del-fuero-militar

59 Yesid Reyez Alvarado, El nuevo fuero penal militar, Periódico El Espectador, December 20, 2012, http://www.elespectador.com/opinion/ columna-393572-el-nuevo-fuero-penal-militar

60 Gustavo Gallón, Santo Domingo y Fuero Militar, Periódico El Espectador, December 26, 2012, http://www.elespectador.com/opinion/ columna-394179-santo-domingo-y-fuero-militar
Professor Uprimny Yepes suggested in several articles $^{61}$ that the reform should be withdrawn not only because was it unnecessary but because it was openly unacceptable both in relation to Colombia's fulfillment of international human rights obligations and contrary to the purpose of strengthening Colombia's security forces, as it could plant seeds of doubt in international tribunals about Colombian's disciplinary authorities and it's military jurisdiction .

International critics, however, presented the most radical and almost unanimous opposition to the proposal. Critiques came from international institutions and international NGOs alike, with Human Rights Watch (HRW) taking the most active role in publicly opposing the reform. In October 2012, HRW's Executive Director for the Americas division wrote a public letter to President Santos expressing the organization's “deep concern" about the constitutional reform, stating that that the "legal insecurity" argument used to support the amendment was itself a "myth" 62 . In an effort to debunk this "myth", the letter cited several reports by Colombia's Defense Minister dating back to 2009 that listed Colombian security forces as having killed 1,964 members of the guerrillas and paramilitary successor groups in combat. These high numbers of killings clearly showed that Colombia's military had no qualms about continuing to take down enemy comba-

61 Rodrigo Uprimny Yépez, Comentarios Dejusticia a la Reforma Constitutional al Fuero Militar, December 10, 2012, http://www.dejusticia.org/index.php?modo=interna\&tema=estado_de_derecho\&publicacion=1395

José Miguel Vivanco, Open letter to President Juan Manuel Santos Against the Reform to the Military Forum, October 25, 2012, http:// www.hrw.org/es/news/2012/10/25/colombia-carta-al-presidente-santos-criticando-ampliaci-n-del-fuero-militar 
tants, despite any opaqueness in the law. According to the letter, if the Government's hypothesis was correct, then hundreds if not thousands of military personnel would be under investigation by the Attorney General's Office for alleged extrajudicial execution. In fact, argued HRW, the Attorney General's Office had only opened 22 investigations involving army members for presumed extrajudicial executions committed between 2009 and August, 2012. Along this line of reasoning, the letter concluded with,

Colombia's military is not afflicted with "legal insecurity". If military members fear prosecution for lawfully killing, then the Minister of Defense should review its training programs in order to correct this misperception. And if your administration is concerned with accelerating investigations of military abuses, it should strengthen the civilian justice system. But it would be a mistake to deliver an unprecedented blow to the rule of law in order to fix a problem that does not exist ${ }^{63}$.

Thus, according to HRW the reform was unnecessary and unjustified because the bedrock of the reform did not have any real or factual support.

From international institutions, critics of the reform came mainly from human rights treatybodies. For example, Todd Howland, representative for the UN High Commissioner or Human Rights in Colombia, expressed his organization's opposition to the proposal ${ }^{64}$. In doing so, the

63 Id.

64 Todd Howland, Panel Constitution y Fuero Militar, August 30, 2012, p. 11, http://www.hchr.org.co/publico/pronunciamientos/ponencias/ po144.pdf representative argued that the reform was not required to overcome the difficulties involved in the military's liability for human rights violations and moreover the reform served as a step backward in the operation and functioning of the administration of justice in the country. Mr. Howland argued that the normative measures adopted and employed since 2008 were adequate in controlling and dissuading the military from committing human rights violations and the extrajudicial executions of civilians, such as those seen in the "false positives" scandal. Mr. Howland was emphatic in stating that the idea of "legal insecurity", was "wrongful and must be corrected. No soldier is going to prison for combating the guerrillas within the framework of the International Humanitarian Law. Our office has not found any case in which that has occurred"65. His arguments, although compelling, were disregarded by the Colombian government.

The Special Procedures mandate-holders of the Human Rights Council agreed with Mr. Howland's analysis and also wrote an open letter to Colombia's government and congressional representatives expressing their concern about the possible adoption of the reform and called for the bill's withdrawal ${ }^{66}$. To the mandate-holders, this proposal could seriously undermine the administration of justice in cases of alleged violations of human rights and international humanitarian law, including serious crimes

65 Id

66

Open letter by Special Procedures mandate-holders of the Human Rights Council to the Colombian government and its congressional representatives, October 22, 2012, http://www.ohchr.org/EN/NewsEvents/Pages/DisplayNews.aspx?NewsID=12683\&LangID=E 
committed by military or police forces. The letter stated that "such a reform would represent a historic setback to the progress achieved by the State of Colombia in the fight against impunity and respect and guarantee of human rights" 67 .

Finally, the Inter-American Commission on Human Rights made an in loco visit to Colombia in December 2012 and in its preliminary observation $^{68}$ affirmed that if the draft of the constitutional reform was approved the Commission would consider several of its provisions to be incompatible with the American Convention on Human Rights. In the words of the Commission,

The adoption of the constitutional reform as it is currently drafted, even after the changes introduced during the seventh debate, would constitute a serious setback and put at risk the victims' right to justice. The IACHR urges Congress not to enact the law in this version and to make changes that accord with its constitutional duty to comply with the standards of the Inter-American System of Human Rights ${ }^{69}$.

Thus, it was clear that congressional approval of the reform would compromise Colombia's profile before the Inter-American System of Human Rights.

Despite these numerous coercive arguments, especially from the international arena, the Colombian government called on Congress to

67 Id.

68

Inter-American Commission on Human Rights, Preliminary Observations on Its Onsite Visit to Colombia, December 7, 2012, http://www. oas.org/en/iachr/media_center/PReleases/2012/144A.asp

69 Id. ignore the critics and to move forward with the reform's approval. The Minister of the Interior, Fernando Carrillo Flórez, referred to the idea of "legislative sovereignty" 70 in reaction to the critiques made by international institutions and called for the reform's enactment. From the Colombian government's perspective, the reform did not give the military carte blanc to act as it pleased and thus would not result in impunity. On the contrary, the government argued that the reform provided legal assurances to the military and State police by providing them with a clear legal framework under which they understood the consequences of their actions when fighting in combat ${ }^{71}$. Congress shared this opinion and approved the constitutional amendment on December $13,2012^{72}$.

\section{The Constitutional reform's content and implications}

Just days after the amendment's approval, President Santos publicly approved of the reform in a speech made at one of the country's largest military forts, In his speech he stated that "[t] he military forum seeks that the phantom of the fear will disappear once for all"73. On December

70 Gobierno acude a "soberanía legislativa" en fuero militar. Periódico El Espectador, 11 de diciembre de 2012, http://www.elespectador.com/ noticias/politica/articulo-391861-gobierno-acude-soberania-legislativafuero-militar

71 http://www.elespectador.com/noticias/politica/articulo-392044-fueromilitar-no-un-cheque-blanco-los-militares-gobierno

72 Congreso de la República [National Congress], Gaceta del Congreso [Congress Gazette], No. 930, December 13, 2012

73 El fuero militar busca acabar con el fantasma del miedo: Santos. Periódico El Espectador, http://www.elespectador.com/noticias/judicial/ articulo-393695-el-fuero-militar-busca-acabar-el-fantasma-del-miedosantos 
27,2012 , he officially promulgated Legislative Act 02 of 2012.

This newly enacted Legislative Act had a significant impact on Colombia's legal system. The subjective and functional elements required for military jurisdiction remained unchanged in Article 221 and military courts continued to be composed of retired or active duty military. However, under Legislative Act 02 of 2012 military courts now had exclusive jurisdiction to hear and try IHL related infractions, except for crimes against humanity, genocide, forced disappearances, extrajudicial executions, sexual violence, torture and forced displacement, which were solely reserved for the ordinary courts. Likewise, this new constitutional amendment granted the newly created Penal Guarantees Court (Tribunal de Garantías Penales) national jurisdiction over ordinary and military criminal authorities. These courts replaced the Superior Council of Judicature in settling jurisdictional disputes between military and ordinary tribunals.

This constitutional amendment also created a Technical Coordination Committee composed of judicial police from military and ordinary courts in situations where doubt existed about a court's ability to hear a certain case. Therefore, the military jurisdiction had judicial police but they were only reserved to handle competence issues. Under the new law, military and ordinary courts had to "always" apply IHL as a substantive framework for acts committed in connection with the armed conflict. The new law also allowed for Police Criminal Jurisdiction and the Police Criminal Code to be created by ordinary law and held that any other aspects related with military jurisdiction would be regulated by statutory law enacted by the Congress and proposed by the Government.

The following flowchart further helps in understanding the changes that this successful, but temporary, attempt at constitutional form had on how the courts handled crimes involving $\mathrm{IHL}$ violations.

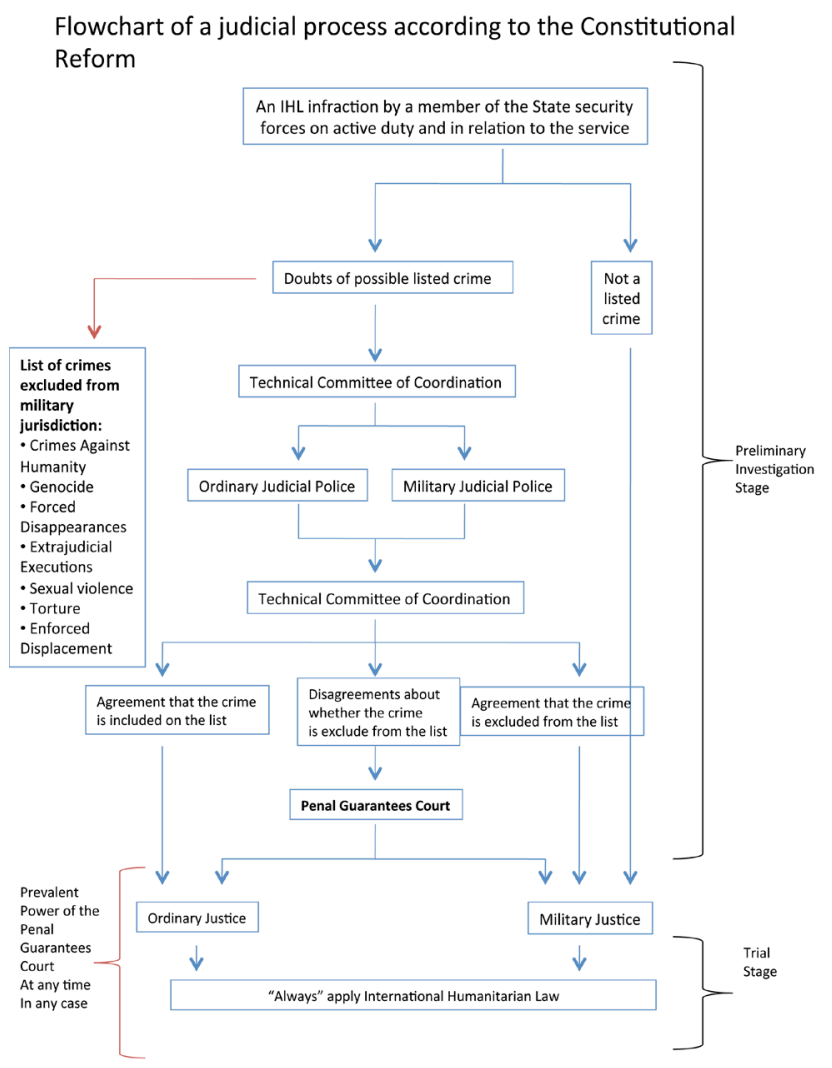

Source: Author's elaboration.

\section{The un-constitutionality of Legislative Act 02 of 2012}

According to article 241.1 of the Colombian Constitution, the Constitutional Court is competent to hear and judge claims made in regard to a legislative act or any other constitutional 
reform for flaws committed during the approval process in accordance with the Constitution and the Congressional Organic Statute ${ }^{74}$. If a citizen presents such a claim, the Constitutional Court may then determine if any procedural defect occurred during the legislative approval process. If the decision is affirmative, the Court may declare the procedural error as a rectifiable defect and return it to Congress for correction. Alternatively, should the Court conclude that the procedural error cannot be ameliorated then the bill and all its legal effects are declared unconstitutional.

In February 2013, some members of congress and a group of influential journalists presented a claim before the Court arguing the unconstitutionality of Legislative Act 02 of 2012 based on a series of defects during the Congressional approval process of the reform. The group alleged various procedural defects. However, their main argument was the coincidence of two simultaneous sessions of the Commission and the Plenary during the first debate in the House of Representatives, which was in direct violation of the legislative approval process. The group also argued that the Act should be declared unconstitutional based on (i) violations to the agenda by the House of Representatives during the proposal's debate; and (ii) the inclusion of modifications to the reform, such as the ability

74 In recent Colombian history, the Constitutional Court has declared some constitutional reforms as unconstitutional based on procedural defects during the legislative approval process. Thus, precedent exists to decide these types of cases. The most significant and famous case was the unconstitutional declaratory judgment of Legislative Act 02 of 2003, also called as "the antiterrorism statute", in which the Court in Decision C-816 of 2004 decided to repeal the constitutional reform due to an omission during the legislative voting process, a defect which the Court declared irreparable. Cfr. Corte Constitutional [C.C.] [Constitutional Court], Augusta 30, 2004, Sentencia C- 816 de 2004. of the Penal Guarantees Court to settle jurisdictional disputes, that were not directly relevant to the original proposal and were introduced only on the last stage of the process. Despite the force and consistency of these arguments, the Constitutional Court still had to review the entire legislative approval process according to the "due legislative process" guidelines and make a determination on the constitutionality of the proposed reform according to these procedural standards.

The Constitutional Court analyzed the claimants' arguments and on October 23, 2013, in a 5 to 4 decision, held that there was an unrectifiable defect during the legislative approval process and thus declared Legislative Act 02 of 2012 unconstitutional and unable to be returned to Congress ${ }^{75}$. According to the Court, the simultaneity of two parliamentary debates in the House of Representatives among other circumstances "evidenced that the real discussion of the reform took place under irregular conditions, which are incompatible with the principles of pluralism, transparency and respect for the political minorities involved in debates concerning a constitutional amendment"76. Thus, the error was deemed un-rectifiable and Legislative Act 02 of 2012 was declared un-constitutional on procedural grounds.

The Court's decision did not go unnoticed. The dissenting justices each filed an opinion, with

\footnotetext{
75 Constitutional Court Decision C-740 of 2013

76 Id.
} 
one of them accusing the majority of "inventing" 77 a new procedural defect to avoid a discussion about the reform's substantial content and its implications on the constitutional framework. President Santos lamented the decision, stating that the military forum exists with or without the constitutional reform, and announcing that he would personally file a bill in the next legislative period to counter the Court's ruling ${ }^{78}$. Likewise, some members of congress hailing from the major political parties argued that the amendment was vital and requested the government to present the same bill to Congress once again ${ }^{79}$.

\section{CONCLUSIONS}

From 1991 until Congress's 2012 attempt to reform Colombia's constitution, the country had tended to restrict the scope of the military jurisdiction. During that time, Colombia's Constitutional Court required military perpetrators of human rights violations, extrajudicial executions and acts that breached International Humanitarian Law to be investigated and prosecuted by ordinary courts. This resulted in a decline in the levels of impunity affiliated with such crimes,

$77 \quad \mathrm{Id}$

78 Gobierno presentará al Congreso un proyecto con mensaje de urgencia para retomar aspectos más importantes de la reforma al Fuero Militar. Página oficial de la Presidencia de la República de Colombia, October 25, 2013, http://wsp.presidencia.gov.co/Prensa/2013/Octubre/Paginas/20131025_07-Gobierno-presentara-Congreso-proyectomensaje-urgencia-retomar-aspectos-mas-importantes-reforma-FueroMilitar.aspx

79 Opiniones divididas en el Congreso por caída del fuero militar. Periódico El Tiempo, October 24, 2013, http://www.eltiempo.com/archivo/ documento/CMS-13141217 most of which were carried out in the context of Colombia's armed conflict.

Nevertheless, high ranking police and military commanders began to grow fearful and paranoid about being investigated and prosecuted under Colombia's ordinary jurisdiction and according to human rights law standards for actions committed during the armed conflict. Although these officers were unable to show any real basis for such paranoia, the Colombian government led an initiative to amend the country's constitution, arguing that too many soldiers and police officers were being removed from the battlefield in order to attend new judicial proceedings and that such proceedings had spawned a lack of initiative or even inactivity among the military units and its Commanders who feared incarceration for having participated in combat actions against guerrilla groups. The government argued that the courts needed to provide the State's security forces with procedural and substantive legal "certainty" in order for them to be fully operable and that the only way to do this was to expand military jurisdiction by way of a constitutional amendment.

Despite outcries of resistance from international institutions and domestic and international NGOs, Congress passed the reform in the final days of 2012. Ten months later, the Constitutional Court in a controversial decision declared the reform unconstitutional due to some irreparable procedural defects during the legislative approval process, specifically focusing on the two simultaneous sessions of the Commission and the Plenary in first debate in the House of Repre- 
sentatives. Despite this decision, the Colombian government and leaders from the major political parties in Congress have vowed to present the bill again as they argue that the procedural defects which the Court uses as justification for overturning the bill are only formalities and not substantial enough to merit such a retraction.

Thus, under the imminence of this future proposal, all the points discussed above will very likely be publicly addressed and rigorously debated once again. In order for responsible future debates to take place on these issues, the starting point must be an analysis of why Legislative Act 02 of 2012 failed, taking into account the political and historical context and legislative history which may have played a role in the Court's decision. If the subsequent debates do so, this paper will have served its purpose.

\section{Bibliography}

Alston, P. (March 31, 2010). "Report of the Special Rapporteur on extrajudicial, summary or arbitrary executions- Mission to Colombia", A/HRC/14/24Add.2, Available at:http://daccess-dds-ny.un.org/doc/UNDOC/GEN/G10/132/35/PDF/G1013235. pdf?OpenElement

Andreu-Guzmán, F. (2004). Military Jurisdiction and International Law: Military Courts and Gross Human Rights Violations. Geneva: International Commission of Jurists.

Consejo Superior de la Judicatura [Superior Council of Judicature]. (August 14, 2006).
Sala Jurisdiccional- Disciplinaria, Expediente 11001010200020060112100.

Consejo Superior de la Judicatura [Superior Council of Judicature]. (July 30, 2011). Sala Jurisdiccional- Disciplinaria, Expediente 11001010200020110125700.

Corte Constitutional [C.C.] [Constitutional Court]. (August 21, 2002). Sentencia T-677 of 2002. . (May 28, 2008). Sentencia

C-533/08. . (August 5, 1997). Sentencia C-358/97. . (February 5, 1996). Sentencia C-037/96. . (July 12, 2000). Sentencia C- $878 / 00$. (June 24, 1994). Sentencia T-295/94. (November 13, 2001). Sentencia SU-1184/01. (October 23, 2013). Sentencia C-740/13.

Corte Inter-Americana de Derechos Humanos. (January 27, 2009). Caso Heliodoro Portugal v. Panamá. Serie C No. 186. - (November 24, 2006). Caso Trabajadores Cesados del Congreso 
(Aguado Alfaro y otros) contra Perú. Serie C No. 158.

. (February 5, 2001). Caso

"La última tentación de Cristo" v. Chile. Serie

C No. 73 , punto resolutivo No. 4.

- (November 30, 2012).

Caso Masacre de Santo Domingo v. Colombia. (Excepciones Preliminares, Fondo y Reparaciones), p.48.

Corte Suprema de Justicia [C.S.J] [Supreme Court of Justice]. (March 23, 2011). Casación 35.099.

Draft Principles Governing the Administration of Justice Through Military Tribunals, 62d Sess., UN Doc. E/CN.4/2006/58 (January 13, 2006).

Gibson, M. (2008). International Human Rights Law and the Administration of Justice through Military Tribunals: Preserving utility while precluding impunity. J. Int'I \& Int'` Rel. (4), 1.

Howland, T. (August 30 de 2012). Panel Constitución y Fuero Militar (p.11). Available at: http://www.hchr.org.co/publico/pronunciamientos/ponencias/po144.pdf
Inter-American Commission on Human Rights, IACHR Expresses Concern over Constitutional Reform in Colombia. (January 4, 2013). Available at: http://www.oas.org/en/iachr/media_center/PReleases/2013/004.asp . (1999). Third Report on the Situation of Human Rights in Colombia. Chapter V, p. 9.

- (December 7, 2012).

Preliminary Observations on Its Onsite Visit to Colombia, Available at: http:// www.oas.org/en/iachr/media_center/ PReleases/2012/144A.asp

OHCHR, (January 7, 2013). Annual Report of the United Nations High Commissioner for Human Rights, 2012, A/HRC/22/17/Add.3 (p.16). http://www.hchr.org.co/documentoseinformes/informes/altocomisionado/informe2012en.pdf

Quénivet, N. (2008) The History of the Relationship between International Humanitarian Law and Human Rights Law. In: Roberta Arnold; Noelle Quénivet. International Humanitarian Law and Human Rights Law: Toward a New Merger in International Law. Boston: Martinus Nijhoff Publishers. 